these. Territories covered by the series include Basutoland, Bechuanaland, Congo-Leo, Kenya, Mozambique, Nyasaland, Northern and Southern Rhodesia, Ruanda/Burundi, South Africa, Swaziland, Tanganyika, and Uganda. Further information and catalogues of these records may be obtained from The Director, International Library of African Music, P.O. Box 138, Roodepoort, Transvaal, South Africa.

\title{
Margaret Wrong Memorial Fund: Award for 1962
}

Ar a meeting held in Edinburgh House, London, on ro January 1963 , the Administrative Committee agrẹed that an award should be made to Mallam Abubakar Imam, O.B.E., for his distinguished services as Hausa editor of Gaskiye Ta Fi Kwabo, as Editorial Superintendent with the Northern Region Literature Agency, and for his authorship of fiction, history, and miscellaneous writings. An award was also made to Wole Soyinka, lecturer in the Department of English in the University of Ife, for the originality of his literary contributions as a playwright.

\section{East African Art}

In a paper given to the Commonwealth Section of the Royal Society of Arts, London, on 12 February 1963, Mr. Sam Ntiro, the artist, began with an account of rock and cave paintings in 'Tanganyika. He then went on to discuss ' tourist sculpture ' in East Africa and the concern felt by artists and others at the low standards for which the commercialization of this sculpture must be held responsible. The problem was a difficult one, since no modern country could afford to shut its doors on tourists and the civilizations of other nations. Mr. Ntiro felt that East Africans should first of all cherish and care for their own culture, for it was only after they had experienced this concern that they would be in a position to appreciate and benefit from other forms of culture and so in time raise the general standard of their work. Finally Mr. Ntiro paid tribute to the work of Mrs. Margaret Trowell, the founder of the School of Fine Art at Makerere College, and described the works of some of its students who have since become well-known artists. 